\title{
Effect of heat stress on tonic and GnRH-induced gonadotrophin secretion in relation to concentration of oestradiol in plasma of cyclic cows
}

\author{
E. Gilad, R. Meidan, A. Berman, Y. Graber and D. Wolfenson* \\ Department of Animal Science, Faculty of Agriculture, Hebrew University, Rehovot 76100, Israel
}

\begin{abstract}
Effects of acute and seasonal heat stress on tonic and GnRH-induced LH and FSH secretion were examined during the early follicular phase of the oestrous cycle of cows $(n=40)$. Prostaglandin $\mathrm{F}_{2 \alpha}$ was injected on day $11 \pm 1$ of the oestrous cycle and on the next day blood samples were collected at intervals of $15-20 \mathrm{~min}$ for $14 \mathrm{~h}$, and i.m. injection of GnRH was given after $7 \mathrm{~h}$. Treatments compared were control versus acute heat stress during blood sampling in winter, and cooled versus chronic heat stress in summer. Before GnRH injection, chronic heat stress in summer did not affect basal concentrations of plasma LH, but did lower LH pulse amplitude. However, in cows with low plasma oestradiol ( $\left.1.9 \pm 0.2 \mathrm{pg} \mathrm{ml}^{-1}\right)$, the mean and basal concentrations and amplitude of tonic LH pulses were reduced by heat stress (3.1, 2.1 and 4.8 versus $1.9,1.4$ and $2.5 \mathrm{ng} \mathrm{ml}^{-1}$, respectively). In cows with high plasma oestradiol $\left(6.3 \pm 0.5 \mathrm{pg} \mathrm{ml}^{-1}\right)$, these parameters were not affected. In chronically heat stressed cows in summer, GnRH-induced increases in plasma LH and FSH concentrations were the same as in the cooled controls. However, in cows with low plasma oestradiol, mean concentrations of $\mathrm{FSH}$ in plasma (31.8 versus $25.5 \mathrm{ng} \mathrm{ml}^{-1}$ ), the peak of the GnRH-induced FSH and LH surge (FSH 47.4 versus $35.6 \mathrm{ng} \mathrm{ml}{ }^{-1}, \mathrm{LH} 50.7$ versus $37.3 \mathrm{ng} \mathrm{ml}^{-1}$ ) and the shape of the GnRH-induced FSH and LH curves (treatment by time interaction) were significantly lower in non-cooled versus cooled controls. The GnRHinduced increase in LH secretion was unaffected by chronic heat stress in cows with high concentrations of oestradiol in plasma. In winter, acute heat stress depressed the mean concentration of FSH in plasma and decreased the GnRH-induced release of FSH in cases with low but not with high concentrations of oestradiol in plasma. The peak of the GnRH-induced surge of $\mathrm{LH}$ in all acutely heat stressed cows was significantly lower in winter than in control cows, irrespective of concentrations of oestradiol in plasma. These results show that heat stress affects the secretion of gonadotrophins more in cows with low concentrations of oestradiol than in those with high concentrations of oestradiol in plasma.
\end{abstract}

\section{Introduction}

The low fertility of dairy cattle in summer in subtropical climates is well known. Conception rates in Israel decrease from $52 \%$ in winter to $24 \%$ in summer (Ron et al., 1984), and similar values have been recorded in southern USA (Monty and Wolf, 1974). Fertility has been found to be sensitive to heat stress during the 12 days before oestrus, especially on day 2 before oestrus (Ingraham et al., 1976), the day after oestrus (Badinga et al., 1985), and days 1-7 after artificial insemination (Putney et al., 1989). Cooling cows from days 0 to 8 after oestrus was found to increase conception rates in one study (Stott and Wiersma, 1976), but not in another (Her et al., 1988). Relieving heat stress in summer, from day of calving until 150 days of lactation, increased conception rates to $59 \%$, compared with $17 \%$ for non-cooled controls (Wolfenson et al., 1988).

${ }^{*}$ Correspondence and reprint requests

Received 7 September 1992.
The role of gonadotrophins in the regulation of functions of follicles and the corpus luteum in cattle is well documented (Ireland, 1987). At the beginning of the follicular phase, gonadotrophin secretion increases in a pulsatile pattern and follicular development accelerates until the preovulatory surges of LH and FSH and ovulation. (Ireland and Roche, 1982; Dielman et al., 1986). Disturbances in gonadotrophin secretion during the follicular phase may impair follicular development and ovulation, and the function of the subsequent corpus luteum (McNatty et al., 1981; Quirk and Fortune, 1986).

The effect of heat stress on LH secretion during the follicular phase of the oestrous cycle in cattle is unclear. Concentrations of LH in plasma have been reported to be unchanged (Gwazdauskas et al., 1981; Gauthier, 1986), increased (Roman-Ponce et al., 1981) or decreased (Madan and Johnson, 1973) by heat stress. These discrepancies may be associated with differences in sampling frequency, which varied from once a day to once every $3 \mathrm{~h}$, and depended on whether heat stress was acute or chronic. To the best of our knowledge, the effects of heat stress 
on FSH secretion have not been reported for cows or other mammals.

The work reported here examined the effects of acute and chronic heat stress on tonic and GnRH-stimulated gonadotrophin secretion in lactating cows.

\section{Materials and Methods}

\section{Animals}

The study was carried out on 40 multiparous Israeli-Holstein cyclic dairy cows over 200 days in lactation in the dairy herd of Kibbutz Ketura, located in the desert, south of the Dead Sea.

\section{Experimental protocol}

The oestrous cycles of the cows were synchronized by two injections of $25 \mathrm{mg}$ PGF $_{2 \alpha}$ (Lutalyse: Upjohn, Puurs) administered 14 days apart. On day $11 \pm 1$ of the cycle (day $0=$ oestrus), the presence of a corpus luteum was determined by rectal palpation and a blood sample was taken to determine concentrations of plasma progesterone. $\mathrm{PGF}_{2 \alpha}$ was administered at 10:00 h to induce regression of the corpus luteum, and a heparinized catheter (Abbocath, 16-gauge, $14 \mathrm{~cm}$, Abbott Hospitals, Chicago, IL) was inserted into the jugular vein. Three out of 43 cows were excluded from the experiment because concentrations of progesterone in their plasma were below $0.5 \mathrm{ng} \mathrm{ml}^{-1}$ on day 11, indicating absence of active luteal tissue.

Experiments started the following morning at 06:00 h (on day $12 \pm 1$ of the cycle), $20 \mathrm{~h}$ after the $\mathrm{PGF}_{2 \alpha}$ injection, to ensure low progesterone concentrations well in advance of the endogenous surge of $\mathrm{LH}$. Blood was withdrawn at intervals of $15 \mathrm{~min}$ for $7 \mathrm{~h}$ to determine the pattern of basal LH secretion. After this, $10 \mu \mathrm{g}$ of a $\mathrm{GnRH}$ analogue (Buserelin: Receptal, Hoechst, Munich) was injected i.m. to induce a gonadotrophin surge. Blood was then withdrawn at intervals of $20 \mathrm{~min}$ for a second period of $7 \mathrm{~h}$. Food and water were supplied ad libitum throughout the day. Blood samples were stored on ice for up to $30 \mathrm{~min}$ before centrifugation $(2000 \mathrm{~g}, 20 \mathrm{~min}$ ) and plasma was stored at $-20^{\circ} \mathrm{C}$. Body temperatures were frequently recorded throughout that day.

\section{Thermal treatments}

Experiments were conducted over two years. Each thermal treatment within a year/season was compared with matched contemporary controls (treatments 1 versus 2,3 versus 4 , and 5 versus 6 , as described below). Cows were randomly assigned to treatments in each season according to days in lactation, number of lactations and milk production. Treatment $I$ (control, $n=11$ ) consisted of cows kept under the mild winter conditions of the area; maximum and minimum air temperatures were 25.3 and $15.1^{\circ} \mathrm{C}$, respectively, and outdoor relative humidity at peak air temperature was $35 \%$. Treatment 2 (acute heat stress, $n=8$ ) consisted of animals exposed to winter conditions as described previously, but acutely heat stressed on day 12 at $40^{\circ} \mathrm{C}$ and $60 \%$ relative humidity for $16 \mathrm{~h}$ in a climate chamber. Treatment 3 (summer cooled, $n=5$ ) comprised cows exposed to summer weather: mean maximum and minimum air temperatures and relative humidity were $39^{\circ} \mathrm{C}, 23^{\circ} \mathrm{C}$ and $16 \%$, respectively, under shade. Cows were cooled five times a day for $20 \mathrm{~min}$; this consisted of $1 \mathrm{~min}$ sprinkling and $4 \mathrm{~min}$ forced ventilation cycles. They could also cool themselves voluntarily under sprinklers operating along the manger from 08:00 to 20:00 h daily. The cooling systems and their impact on performance of cows were described in detail in Flamenbaum et al. (1986) and Her et al. (1988). In treatment 4 (summer shaded, $n=5$ ), cows were exposed to similar summer conditions but were offered shade as the only means for heat stress relief. Treatment 5 (summer cooled, $n=4$ ) was identical to treatment 3 , but was carried out the following year to serve as concomitant control for treatment 6 (summer heat stress, $n=7$ ). In the latter, cows were not provided with any means for heat stress relief and were also deprived of shade from 07:00 to 15:00 h. This group was thus exposed to harsher conditions than that in treatment 4 . All summer treatments were applied for 4 weeks before the day of the experiment. Nutrition and management was similar throughout the two-year experiment.

\section{Radioimmunoassay}

LH was determined by double-antibody radioimmunoassay. Plasma samples $(0.1 \mathrm{ml})$ were diluted in $0.4 \mathrm{ml}$ of assay buffer (0.05 mol phosphate-buffered saline $\mathrm{I}^{-1}$, PBS) $\mathrm{pH} 7.4$ and $0.2 \%$ EDTA. Bovine LH-B7 (NIDDK, National Institute of Diabetes, Digestive and Kidney Diseases, Baltimore, MD) was iodinated using the Iodogen method (Fracker and Speck, 1978). Briefly, $20 \mu \mathrm{g} \mathrm{LH}$ was incubated for $4 \mathrm{~min}$ with $1 \mu \mathrm{Ci}{ }^{125} \mathrm{I}-\mathrm{Na}$ in an Iodogen-coated tube. Iodinated $\mathrm{LH}$ was separated from free iodine by anion exchange AG $2^{*} 8$ (BioRad, Richmond, CA). Iodinated LH (100 $\mu$ l, 18000 c.p.m.), diluted in PBS containing $1 \%$ BSA, was added to the samples $(100 \mu \mathrm{l})$ and then anti-ovineLH-B23 (NIDDK), diluted 1:450 000 in $200 \mu$ l PBS containing $1 \%$ normal rabbit serum, was added. At this dilution, a mean of $30 \%$ maximal binding was obtained. Samples were incubated overnight at $22^{\circ} \mathrm{C}$, after which $200 \mu \mathrm{l}$ of anti-rabbit serum IgG raised in goat was added and the mixture was incubated overnight at $4^{\circ} \mathrm{C}$. Bound and free LH were separated by centrifugation at $1500 \mathrm{~g}$ for $15 \mathrm{~min}$, and the supernatant was decanted and radioactivity in the pellet was measured in a gamma counter. The standard curves ranged from 0.078 to $40 \mathrm{ng}$ per tube. Mean \pm SEM of measured concentrations of two known quantities of $\mathrm{LH}\left(34.7\right.$ and $17.3 \mathrm{ng} \mathrm{ml}^{-1}$ ) in plasma samples of dry pregnant cows were $36.6 \pm 2.7$ and $19.5 \pm 1.2$, respectively, which is 5.5 and $12.4 \%$ above the expected values, respectively. Assay sensitivity was $0.1 \mathrm{ng}$ and intra- and interassay coefficients of variation were 3.7 and $6.7 \%$, respectively.

FSH was determined by radioimmunoassay carried out at Colorado State University, Fort Collins, CO, as described and validated by L'Hermite et al. (1972) and Akbar et al. (1974). Samples (pooled at intervals of $1 \mathrm{~h}$ ) obtained after $\mathrm{GnRH}$ administration were used, and samples from only half the cows were used from treatment 1 . Assay sensitivity was $2 \mathrm{ng}$ per tube, and intra- and interassay coefficients of variation were 5.7 and $16.1 \%$, respectively. Concentrations of plasma progesterone were determined by radioimmunoassay after petrol ether extraction (Bauminger et al., 1974; Meidan et al., 1990). Mean 
assay sensitivity was $10 \mathrm{pg}$ per tube, and intra- and interassay coefficients of variation were 5.1 and $5.6 \%$, respectively. Oestradiol was determined by radioimmunoassay, in one assay, after di-ethyl ether extraction at the Agricultural Research Organization (Volcani Center), Rehovot (Rosenberg et al., 1987). Intra-assay coefficient of variation was $13.0 \%$. Assay sensitivity was $1.0 \mathrm{pg}$ per tube.

\section{Statistical analysis}

Statistical analyses were performed separately within each season (winter or summer), owing to the different nature of the thermal treatments (short-term in winter versus long-term in summer), as well as differences in other seasonal characteristics such as photoperiod. For LH, the Pulsar Algorithmic Procedure (Merriam and Wachter, 1982) was used to calculate the overall mean, baseline (mean excluding peak values), pulse amplitude and pulse frequency before GnRH injection. Parameters were then analysed by the General Linear Model (GLM) procedures of the Statistical Analysis System (SAS User's Guide, 1985). The repeated measures routine was used to analyse $\mathrm{LH}$ and FSH following GnRH injection. Thermal treatment was taken as the main effect and was tested with cows within treatments as the error term. For time effect and treatment by time interaction, residual variance was used as the error term. Peak LH and FSH surges after GnRH injection were examined by one-way analysis of variance. The effects of year and interactions with treatments and time were examined to determine whether $\mathrm{LH}$ and FSH data from similar thermal treatments for both summers could be pooled.

\section{Results}

\section{Body temperature}

The mean maximal body temperatures of winter heat stressed, and first summer and second summer heat stressed cows were significantly higher than those of respective controls $\left(39.5 \pm 0.1^{\circ} \mathrm{C}\right.$ versus $38.3 \pm 0.1^{\circ} \mathrm{C} ; 39.1 \pm 0.1^{\circ} \mathrm{C}$ versus $38.7 \pm 0.2^{\circ} \mathrm{C} ; 39.4 \pm 0.1^{\circ} \mathrm{C}$ versus $38.4 \pm 0.2^{\circ} \mathrm{C}$ respectively, $P<0.01$ ). Body temperature of the summer heat stressed shaded group (first summer) was lower than that of the summer chronically heat stressed group (second summer).

\section{Steroid concentrations in plasma}

Plasma progesterone concentrations (means \pm SEM) before PGF $_{2 \alpha}$ administration (day $11 \pm 1$ of the oestrous cycle), at 07:00 and 13:00 h on the day of the experiment (day $12 \pm 1$ ), and at 09:00 on the next day were 6.1 $\pm 0.7,0.9 \pm 0.1$, $0.6 \pm 0.05$ and $0.2 \pm 0.01 \mathrm{ng} \mathrm{ml}^{-1}$, respectively. These data clearly indicated corpus luteum regression following $\mathrm{PGF}_{2 \alpha}$ injection. Progesterone values on the day of the experiment (day 12) were below the concentrations reported to inhibit gonadotrophin secretion (Schallenberger et al., 1984). The concentrations of oestradiol in plasma samples taken on the day of the experiment during the first $2 \mathrm{~h}$ of collection of blood samples, before GnRH challenge, averaged $4.6 \pm 0.7 \mathrm{pg} \mathrm{ml}^{-1}$
Table 1. Mean and peak concentrations of plasma LH and FSH (ng $\mathrm{ml}^{-1}$ ) after an i.m. injection of $\mathrm{GnRH}$ in cows with high and low concentrations of plasma oestradiol

\begin{tabular}{lcc}
\hline Parameter & $\begin{array}{c}\text { Low oestradiol } \\
\left(<3.3 \mathrm{pg} \mathrm{ml}^{-1} ; n=18\right)\end{array}$ & $\begin{array}{c}\text { High oestradiol } \\
\left(>3.4 \mathrm{pg} \mathrm{ml}^{-1} ; n=22\right)\end{array}$ \\
\hline LH & & \\
$\quad$ Mean & $16.5 \pm 1.9$ & $18.6 \pm 1.5$ \\
Peak & $37.7 \pm 5.6$ & $51.9 \pm 4.5^{*}$ \\
FSH & & \\
Mean & $30.7 \pm 1.5$ & $35.6 \pm 1.3^{* *}$ \\
Peak & $44.4 \pm 2.5$ & $56.2 \pm 2.2^{* *}$ \\
\hline
\end{tabular}

Values are means \pm SEM.

Significant differences between groups $\left({ }^{*} P<0.06 ;{ }^{* *} P<0.01\right)$.

(range $0.5-10.2 \mathrm{pg} \mathrm{ml}^{-1}$ ). Progesterone and oestradiol concentrations did not vary with thermal treatments (data not shown).

Cows were classified into two groups on the basis of the concentration of oestradiol in their blood: a 'low' oestradiol group, in which the oestradiol concentration was below $3.3 \mathrm{pg}$ $\mathrm{ml}^{-1}\left(1.9 \pm 0.2 \mathrm{pg} \mathrm{ml}^{-1}, n=18\right)$, and a 'high' oestradiol group, in which oestradiol values were above $3.4 \mathrm{pg} \mathrm{ml}^{-1}$ $\left(6.3 \pm 0.5 \mathrm{pg} \mathrm{ml}^{-1}, n=22\right)$. In the high oestradiol group, GnRH-induced LH and FSH peak values and the mean FSH concentration were significantly higher than those in the low oestradiol group (Table 1). In addition, their interaction with time after administration of $\mathrm{GnRH}$ was statistically significant $(P<0.01)$.

Examination of the pooled LH data for basal concentrations and $\mathrm{GnRH}$-induced release showed no significant difference, or a non-significant trend between the same thermal treatments carried out in the two consecutive summers. The LH data were therefore pooled to increase the number of animals in each treatment group. A year effect was detected $(P<0.06)$ for $\mathrm{FSH}$ concentrations in plasma and these were therefore analysed separately for the first and second summers.

\section{Pattern of $L H$ secretion before administration of $G n R H$}

The effect of acute heat stress in winter on the pulsatile pattern of LH secretion was not assessed, as blood samples were not collected sufficiently frequently. In summer, the mean tonic concentrations of LH in plasma as well as LH baseline and pulse frequency were not affected by chronic heat stress. However, LH pulse amplitude was $30 \%$ smaller in non-cooled than in cooled cows $(P<0.05$, Table 2$)$. In the cows with high concentrations of oestradiol in plasma, chronic heat stress had no effect on tonic LH secretion (Table 2). In the group with low concentrations of oestradiol in plasma, LH pulse amplitude in chronically heat stressed cows was $50 \%$ lower $(P<0.05)$ than in control cows. The mean and baseline concentrations of plasma LH in the group with low concentrations of plasma oestradiol were also lower in chronically heat stressed than in control cows (Table 2). Chronic heat stress did not modify LH pulse frequency (Table 2). 
Table 2. Concentrations of mean and baseline plasma LH and LH pulse amplitude and frequency in cows subjected to chronic heat stress in summer

\begin{tabular}{|c|c|c|c|c|c|c|}
\hline Plasma LH & Control & Heat stressed & Control & Heat stressed & Control & Heat stressed \\
\hline$n$ & 9 & 12 & 6 & 6 & 3 & 6 \\
\hline Mean (ng ml ${ }^{-1}$ ) & $2.7 \pm 0.3$ & $2.2 \pm 0.5$ & $3.1 \pm 0.3$ & $1.9 \pm 0.6 \dagger$ & $1.9 \pm 0.3$ & $2.0 \pm 0.3$ \\
\hline Baseline $\left(\mathrm{ng} \mathrm{ml}^{-1}\right)^{\mathrm{a}}$ & $1.9 \pm 0.2$ & $1.6 \pm 0.4$ & $2.1 \pm 0.2$ & $1.4 \pm 0.4$ & $1.6 \pm 0.3$ & $1.3 \pm 0.3$ \\
\hline
\end{tabular}

Values are means \pm SEM

Significant differences between treatments $\left({ }^{*} P<0.05 ; \dagger P<0.07\right)$.

Mean, excluding pulses.

$n$ : number of cows.
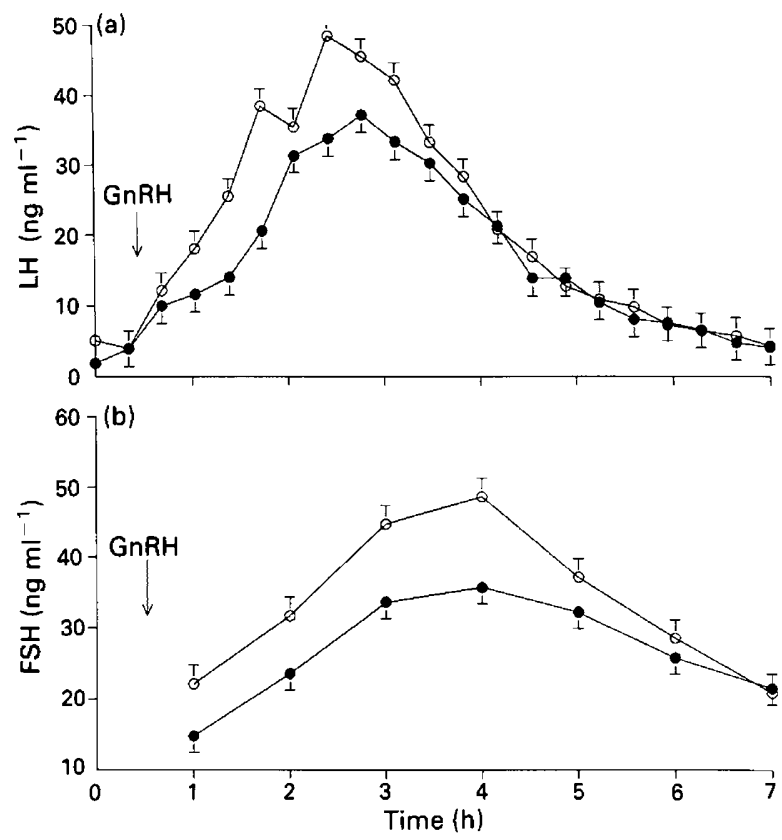

Fig. 1. Mean $( \pm S E M)$ plasma gonadotrophin concentrations, after $\mathrm{GnRH}$ challenge in cows in summer at the beginning of the follicular phase, with low concentrations of plasma oestradiol and subjected to heat stress (non-cooled). (a) LH of cooled $(\mathrm{O})$ and non-cooled (O) cows; (b) FSH of cooled $(O)$ and non-cooled $(O)$ cows.

\section{LH secretion after the administration of $\mathrm{G} n \mathrm{RH}$}

The data for $\mathrm{LH}$ measurements after GnRH administration were analysed separately for summer (two years pool; Fig. Ia) and winter (Fig. 2a). In the summer, the overall mean concentration of LH in control $(n=9)$ and chronically heat stressed $(n=12)$ cows $\left(18.9 \pm 2.2\right.$ versus $\left.17.9 \pm 1.9 \mathrm{ng} \mathrm{ml}^{-1}\right)$, and the peak of the GnRH induced LH surge in control and chronically heat stressed cows $\left(48.9 \pm 5.5\right.$ versus $\left.44.8 \pm 6.3 \mathrm{ng} \mathrm{ml}^{-1}\right)$ did not differ. Similarly, no trend was noted between treatments in cows with high concentrations of plasma oestradiol (means: $15.7 \pm 4.6$ versus $17.1 \pm 4.5 \mathrm{ng} \mathrm{ml}^{-1}$; peaks: $45.3 \pm 10.6$ versus $43.8 \pm 10.6 \mathrm{ng} \mathrm{ml}^{-1}$, for control $(n=3)$ and chronically heat stressed cows $(n=6)$, respectively). In cows with low concentrations of plasma oestradiol, peak LH release was $27 \%$ lower in heat stressed than in control cows $(P<0.10)$. In cows with low concentrations of plasma oestradiol, the pattern of GnRH-induced LH release differed, with concentrations of plasma LH increasing more rapidly in control than in the chronically heat stressed groups (treatment $x$ time interaction, $P<0.01$, Fig. 1a). There was no significant effect of heat stress on plasma LH concentrations after the GnRH-induced peak had been reached.

In the winter, the mean concentration of plasma $\mathrm{LH}$ in all control cows $(n=11)$ tended to be higher than that of heatstressed $(n=8)$ cows (19.7 \pm 2.1 versus $14.1 \pm 2.6 \mathrm{ng} \mathrm{ml}^{-1}$, respectively, $P<0.1$ ). The peak of the $\mathrm{GnRH}$-induced $\mathrm{LH}$ surge was $34 \%$ lower $\left(54.2 \pm 6.6\right.$ versus $36.0 \pm 7.7 \mathrm{ng} \mathrm{ml}^{-1}$, $P<0.05)$ in the heat-stressed animals. Heat stress did not affect these parameters in cows with high concentrations of plasma oestradiol (means: $20.7 \pm 2.8$ versus $15.8 \pm 3.8 \mathrm{ng} \mathrm{ml}{ }^{-1}$; peaks: $59.7 \pm 9.2$ versus $42.9 \pm 11.6 \mathrm{ng} \mathrm{ml}^{-1}$, for control $(n=8)$ and heat-stressed cows $(n=5)$, respectively). In heat stressed animals with low concentrations of plasma oestradiol, the peak of the $\mathrm{GnRH}$-induced $\mathrm{LH}$ surge tended to be lower $(38 \%$, $P<0.10$ ) than in control cows (Fig. 2a). The GnRH-induced LH surge in the heat stressed cows also tended to be attenuated compared with that in control cows (Fig. 2a, treatment by time interaction, $P<0.10$ ).

\section{FSH after administration of $\mathrm{G} n R H$}

The mean concentrations of plasma FSH, and the peaks of GnRH-induced FSH surges in all cows in the first and second summers were virtually identical in control $(n=9)$ and chronically heat stressed $(n=12)$ groups (means: $31.3 \pm 2.2$ versus $31.0 \pm 2.0 \mathrm{ng} \mathrm{ml}^{-1}$; peaks: $51.6 \pm 5.1$ versus $50.1 \pm 4.3 \mathrm{ng}$ $\mathrm{ml}^{-1}$, respectively). This indicates that, on average, heat stress had no effect on plasma FSH concentration. However, in animals with low concentrations of plasma oestradiol in the second summer, heat stress reduced the mean concentration of plasma FSH to $81 \%$ of that in the control cows $(n=4$; $P<0.05$; Fig. $1 \mathrm{~b}$ ) and reduced the peak of the GnRH-induced FSH surge to $75 \%$ of that of control cows $(35.6 \pm 2.3$ versus 

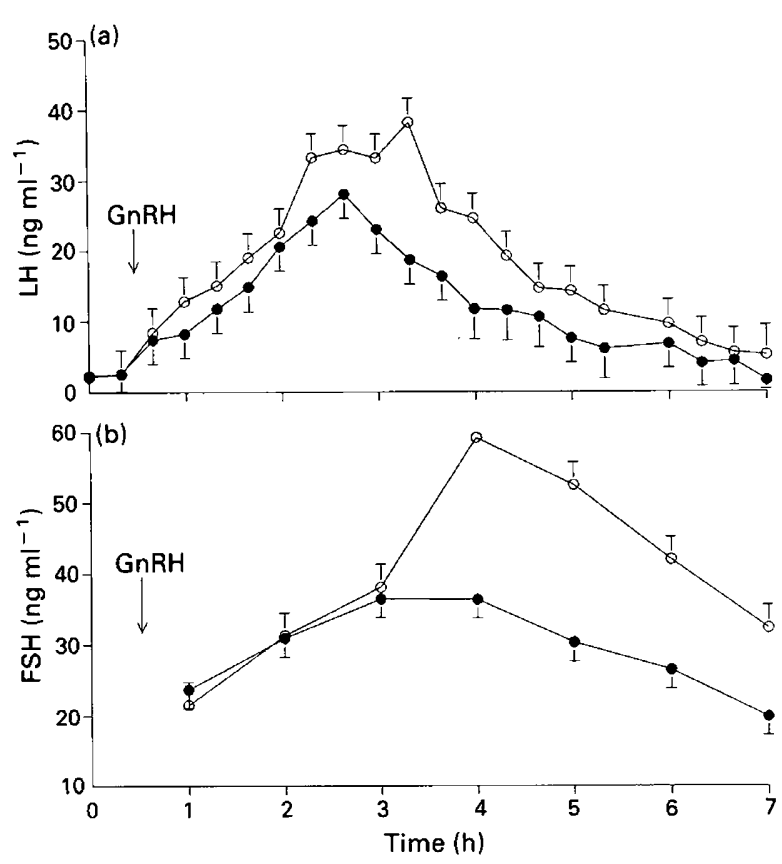

Fig. 2. Mean ( \pm SEM) plasma gonadotrophin concentrations after $\mathrm{GnRH}$ challenge in cows in winter at the beginning of the follicular phase, with low concentrations of plasma oestradiol and subjected to heat stress. (a) $\mathrm{LH}$ of control $(\mathrm{O})$ and heat-stressed ( $)$ cows; (b) FSH of control $(O)$ and heat-stressed $(O)$ cows.

$47.4 \pm 5.1 \mathrm{ng} \mathrm{ml}{ }^{-1}, P<0.01$ ). The number of animals observed in the first summer was too small to classify them by concentrations of plasma oestradiol. Thermal stress altered the pattern of the GnRH-induced FSH surge in cows with low concentrations of plasma oestradiol (treatment by time interaction, $P<0.01$ ), by reducing plasma FSH more than in control cows (Fig. 1b).

In winter, the overall mean concentration of FSH in control $(n=7)$ and heat-stressed cows $(n=8)$ did not differ (36.1 \pm 2.1 versus $31.7 \pm 1.9 \mathrm{ng} \mathrm{ml}^{-1}$, respectively), whereas the peak of the GnRH-induced FSH surge tended to be lower in the latter $\left(56.1 \pm 4.1\right.$ versus $46.4 \pm 3.6 \mathrm{ng} \mathrm{m}^{-1}$, respectively, $P<0.08$ ), and the overall curve was lower in the heat-stressed group (treatment by time interaction, $P<0.05$ ). The concentration of plasma FSH concentrations in cows with high concentrations of plasma oestradiol were similar in control $(n=4)$ and heat-stressed $(n=6)$ groups (means: $35.0 \pm 2.8$ versus $33.9 \pm 2.5 \mathrm{ng} \mathrm{ml}^{-1}$; GnRH-induced peaks: $54.6 \pm 4.9$ versus $51.8 \pm 4.4 \mathrm{ng} \mathrm{ml}^{-1}$, respectively). In contrast, in cows with low concentrations of plasma oestradiol, heat stress significantly $(P<0.01)$ reduced the mean concentration of FSH to $73 \%$, and the peak of the GnRH-induced FSH surge to $63 \%$ of that of control animals (peaks: $59.2 \pm 3.3$ versus $37.3 \pm 2.7 \mathrm{ng} \mathrm{ml}^{-1}$ ).

\section{Discussion}

The objective of this study was to investigate the effects of hyperthermia on gonadotrophin secretion during the early fol- licular phase when the pituitary gland is expected to be highly responsive to $\mathrm{GnRH}$ after the regression of the corpus luteum and removal of the negative feedback effect of progesterone (Ireland and Roche, 1982). Experiments were conducted before the preovulatory surge in gonadotrophin secretion was initiated. The wide range of concentrations of plasma oestradiol in each group of cows indicated the stage of the oestrous cycle at which $\mathrm{PGF}_{2 \alpha}$ was administered. During this stage (days 10-12), the first follicular wave is replaced by a second wave (Fortune et al., 1991). Cows with high concentrations of plasma oestradiol probably had an oestrogen-active, dominant follicle in the first or second wave. In cows with low concentrations of plasma oestradiol, the dominant follicle in the first wave may have become atretic and the dominant follicle in the second wave may have been poorly developed. The concentrations of plasma oestradiol in the low and high oestrogen groups are within the range previously reported for early follicular phase, and with the higher concentrations found prior to the preovulatory surge of plasma oestradiol (Schallenberger et al., 1984; Imakawa et al., 1986).

The ratio of cows with high and low concentrations of plasma oestradiol was approximately $1: 1 \quad n=18$ and 22, respectively). However, further analysis of seasonal differences (independent of the thermal treatments within season) on the ratio of cows with high and low concentrations of oestradiol indicated that (i) the number of cows with low and high concentrations of oestradiol was 6 and 13 in winter, respectively, and in summer 12 and 9 cows, respectively. Chi-square analysis indicates that these differences were not, however, statistically significant $(P<0.10)$ and suggests that chronic heat stress may affect follicular development.

Two major points emerged from an analysis of the LH data collected from cows in the summer: (i) chronic heat stress had no effect on tonic LH secretion or GnRH-induced LH release in cows with high concentrations of plasma oestradiol and (ii) chronic heat stress depressed LH and FSH concentrations in cows with low concentrations of plasma oestradiol.

The reduction in mean and baseline tonic $\mathrm{LH}$ concentrations before $\mathrm{GnRH}$ injection in chronically heat stressed cows with low concentrations of plasma oestradiol in summer are in agreement with similar effects of heat stress in ovariectomized ewes (Schillo et al., 1978). Heat stress did not alter LH pulse frequency in ovariectomized ewes (Schillo et al., 1978) or in intact cows (this study), whereas in sows heat stress reduced frequency of LH pulses but increased their amplitude (Barb et al., 1991). In cows, LH pulse frequency is reduced by heat stress in early, but not mid-luteal phase of the oestrous cycle (Wise et al., 1988). Changes in tonic LH secretion during the early follicular phase could alter ovarian function. This is suggested by the observation that the impaired LH pulse pattern in ewes may be associated with disturbed timing of ovulation, abnormal corpus luteum function and reduced conception rates (McNatty et al., 1981). Furthermore, Savio et al. (1992) have shown that the pattern of tonic $\mathrm{LH}$ secretion influences the rate of growth and turnover of the dominant follicle in the ovary of cyclic cows.

In studies in which cows were not grouped according to concentrations of plasma oestradiol, heat stress during the oestrous cycle either had no effect on plasma tonic LH (Gwazdauskas et al., 1981), or even increased it (Roman-Ponce et al., 1981). Observations on the effects of heat stress on the 
preovulatory surge of $\mathrm{LH}$ are similarly controversial: a reduction of endogenous LH surge by heat stress was reported in heifers (Madan and Johnson, 1973), but not in cows (Gwazdauskas et al., 1981; Rosenberg et al., 1982; Gauthier, 1986). However, in these studies, the sampling frequency of 3-12 $\mathrm{h}$ may have been inadequate to detect any effects on plasma $\mathrm{LH}$ secretion.

In this study heat stress affected LH secretion mainly in cows with low concentrations of oestradiol. This finding suggests that high concentrations of plasma oestradiol counteract the effects of heat stress, or alternatively, that the neuroendocrine mechanism controlling gonadotrophin secretion is more sensitive to heat stress when concentrations of plasma oestradiol are low than when they are high. This could be due to a positive feedback action of oestradiol on gonadotrophin secretion (Kesner et al., 1981; Kesner and Convey, 1982; Schallenberger et al., 1984; Imakawa et al., 1986). In dairy cows, the stimulating effect of oestrogen on LH secretion is proportional to the concentration of oestrogen in the plasma (Dielman et al., 1986; Lucy and Stevenson, 1986). The apparent conflicting observations on the effect of heat stress on $\mathrm{LH}$ secretion may result from the fact that animals were not classified by oestradiol concentrations. The classification of data in this study by concentration of plasma oestradiol resulted in a small number of cows in some subgroups, so that generalizations made should be viewed with caution. However, the similarity of the winter and the summer results strengthens the suggestion that heat stress affects LH and FSH secretion mainly in cows with low concentrations of plasma oestradiol.

Heat stress may affect LH secretion by reducing the amount of $\mathrm{GnRH}$ released during each pulse, consequently reducing gonadotrophin synthesis and hence pituitary gonadotrophin stores. This would account for the decreased pituitary response to $\mathrm{GnRH}$ in heat-stressed animals with low concentrations of plasma oestradiol. This view is consistent with the finding of a lower LH content in the hypophysis of pigs in summer than in winter (Armstrong et al., 1986).

Acute heat stress for $16 \mathrm{~h}$ during the winter season was imposed in this study to examine the effect of short-term heat stress on non-acclimated cows, in contrast to chronic heat stress in summer. The effects of heat stress in the two seasons, though similar in nature, were not similar for all facets of gonadotrophin secretion. In summer, overall mean concentrations of gonadotrophins and peak GnRH-induced surges of LH and FSH were not affected by chronic heat stress, whereas in winter, acute heat stress depressed and $\mathrm{GnRH}$ induced release of gonadotrophins. The marked effects of acute heat stress in winter may be related to the fact that cows in winter are not as well acclimated to heat as they are in summer.

The reduction in gonadotrophin secretion in response to heat stress in winter and summer suggests similar modes of action for both acute and chronic heat stress. Gonadotrophin secretion was induced in this experiment by the same dose of GnRH in all animals. The effects therefore result from a direct effect of heat stress on gonadotrophin secretion. The similarity of the responses to acute and chronic heat stress indicates that the involvement of a possible nutritional deficiency induced by chronic heat stress is not essential to produce the restriction in gonadotrophin secretion. Both secretion and storage of gonadotrophins could be affected, although acute heat stress is expected to affect mainly secretion, whereas chronic heat stress would affect both secretion and storage. This has also been implied in a study on post-weaning primiparous sows, where LH content of the hypophysis was found to be lower in summer than in winter (Armstrong et al., 1986).

The study reported here demonstrates for the first time that FSH secretion is reduced by heat stress, and that this effect is most pronounced in cows with low concentrations of plasma oestradiol. This finding could be related to the previously reported impairment of follicular development by heat stress in cows (Wolfenson et al., 1992). This impairment is reflected by the emergence of fewer small antral follicles, which may be related to the suppression of FSH secretion by heat stress observed here. Reduction in FSH secretion could also affect oestradiol production by follicular granulosa cells.

In conclusion, heat stress, either in its seasonal chronic form or as an acute short-term exposure, affected gonadotrophin secretion during the early follicular phase of the oestrous cycle, mainly in cows with low concentrations of plasma oestradiol. Hyperthermia during this phase may affect tonic LH and preovulatory release of gonadotrophin secretion. The precise nature of the effect of heat stress on gonadotrophin secretion and its relationship to concentration of oestradiol or to the precise stage of the cycle require further investigation.

The authors thank T. Nett (Colorado State University, Fort Collins, USA) for FSH RIA, M. Rosenberg and M. Heler (ARO, Volcani Center) for their help with the oestradiol analysis, NIDDK (MD, USA) for kindly providing LH and LH antiserum, and M. Maman for his technical assistance. Thanks are extended to the dairy herd operators of Kibbutz Ketura (Israel). This work was supported by the Arava Experimental Station grant $820-0027$ and in part by BARD grant IS-1475-88.

\section{References}

Akbar AM, Reichert LE, Dunn TG, Kaltenbach CC and Niswender GD (1974) Serum levels of follicle-stimulating hormone during the bovine estrous cycle Joumal of Animal Science 39 360-365

Armstrong JD, Britt JH and Cox NM (1986) Seasonal differences in function of the hypothalamic-hypophysial-ovarian axis in weaned primiparous sows Joumal of Reproduction and Fertility $\mathbf{7 8} 11-20$

Badinga L, Collier RJ, Thatcher WW and Wilcox CJ (1985) Effects of climatic and management factors on conception rate of dairy cattle in subtropical environment Joumal of Dairy Science 68 78-85

Barb CR, Estienne MJ, Kraeling RR, Marple DN, Rampacek GB, Rahe CH and Sartin JL (1991) Endocrine changes in sows exposed to elevated ambient temperature during lactation Domestic Animal Endocrinology 8 117-127

Bauminger S, Kohen F and Lindner HR (1974) Steroids as haptens: optimal design of antigens for the formation of antibodies to steroid hormones Journal of Steroid Biochemistry 5 739-747

Dielman SJ, Bevers MM, Van Tol HTM and Willemse AH (1986) Peripheral plasma concentrations of oestradiol, progesterone, cortisol, $\mathrm{LH}$ and prolactin during the oestrous cycle in the cow, with emphasis on the peri-oestrous period Animal Reproduction Science 10 275-292

Flamenbaum I, Wolfenson D, Maman M and Berman A (1986) Cooling dairy cattle by a combination of sprinkling and forced ventilation and its implementation in the shelter system Joumal of Dairy Science $693140-3147$

Fortune JE, Sirois J, Turzillo AM and Lavoir M (1991) Follicle selection in domestic ruminants Journal of Reproduction and Fertility 43 187-198

Fracker PJ and Speck JC (1978) Protein and cell membrane iodination with sparingly soluble chloroamide 1,2,4,6-tetradoro $3 \alpha 6 \alpha$ diphenyl-glycouril Biochemical and Biophysical Research Communications 80 849-857

Gauthier D (1986) The influence of season and shade on oestrous behavior, timing of preovulatory LH surge and the pattern of progesterone secretion in FFPN and Creole heifers in a tropical climate Reproduction, Nutrition and Development 26 767-775 
Gwazdauskas FC, Thatcher WW, Kiddy CA, Paape MJ and Wilcox CJ (1981) Hormonal pattern during heat stress following tham salt induced luteal regression in heifers Theriogenology 16 271-285

Her E, Wolfenson D, Flamenbaum I, Folman I, Kaim M and Berman A (1988) Thermal, productive, and reproductive responses of high yielding cows exposed to short-term cooling in summer Joumal of Dairy Science $\mathbf{7 1}$ 1085-1092

Imakawa K, Day ML, Zalesky DD, Garcia-Winder M, Kittok RJ and Kinder JE (1986) Regulation of pulsatile LH secretion by ovarian steroids in the heifer Joumal of Animal Science 63 162-168

Ingraham RH, Stanley RW and Wagner WC (1976) Relationship of temperature and humidity to conception rate of holstein cows in Hawaii Joumal of Dairy Science 59 2086-2090

Ireland J (1987) Control of follicular growth and development journal of Reproduction and Fertility Supplement 34 39-54

Ireland JJ and Roche JF (1982) Development of antral follicles in cattle after prostaglandin-induced luteolysis: changes in serum hormone, steroids in follicular fluid, and gonadotropin receptors Endocrinology 111 2077-2086

Kesner JS and Convey EM (1982) Interaction of oestradiol and luteinizing hormone releasing hormone on follicle stimulating hormone release in cattle Joumal of Animal Science 54 817-821

Kesner JS, Convey EM and Anderson CR (1981) Evidence that estradiol induces the preovulatory LH surge in cattle by increasing pituitary sensitivity to LHRH and then increasing LHRH release Endocrinology 108 1386-1391

L'Hermite M, Niswender GD, Reichert LE and Midgley AR (1972) Serum folliclestimulating hormone in sheep as measured by radioimmunoassay Biology of Reproduction 6 332-352

Lucy M and Stevenson IS (1986) Gonadotropin-releasing hormone at estrus: luteinizing hormone, estradiol, and progesterone during the periestrual and postinsemination period in dairy cattle Biology of Reproduction 35 300-311

McNatty KP, Gibb M, Dobson C and Thurley DC (1981) Evidence that changes in luteinizing hormone secretion regulate the growth of the preovulatory follicle in the ewe Joumal of Endocrinology 90 375-389

Madan ML and Johnson HD (1973) Environmental heat effects on bovine luteinizing hormone Journal of Dairy Science 56 1420-1423

Meidan R, Girsh E, Blum $O$ and Aberdam E (1990) In vitro differentiation of bovine theca and granulosa cells into small and large luteal-like cells: morphological and functional characteristics Biology of Reproduction $\mathbf{4 3}$ 913-921

Merriam GR and Wachter KW (1982) Algorithms for the study of episodic hormone secretion American Journal of Physiology 243 E310-E318

Monty DE and Wolf LK (1974) Summer heat stress and reduced fertility in Holstein-Friesian cows in Arizona American Joumal of Veterinary Research 35 1495-1500
Putney DJ, Drost M and Thatcher WW (1989) Influence of summer heat stress on pregnancy rates of lactating dairy cattle following embryo transfer or artificial insemination Theriogenology $31765-778$

Quirk SM and Fortune JE (1986) Plasma concentrations of gonadotrophins, preovulatory follicle development and luteal function associated with bovine follicular fluid-induced delay of oestrus in heifers Journal of Reproduction and Fertility 76 609-621

Roman-Ponce H, Thatcher WW and Wilcox Cl (1981) Hormonal interrelationships and physiological responses of lactating dairy cows to shade management system in a subtropical environment Theriogenology 16 139-154

Ron M, Bar-Anan R and Wiggans GR (1984) Factors affecting conception rate of Israeli Holstein cattle Joumal of Dairy Science $67854-860$

Rosenberg M, Folman Y, Herz Z, Flamenbaum I, Berman A and Kaim M (1982) Effect of climatic conditions on peripheral concentrations of LH, progesterone and oestradiol-17 $\beta$ in high milk-yielding cows Joumal of Reproduction and Fertility 66 139-146

Rosenberg M, Amir D and Folman Y (1987) The effect of active immunization against progesterone on plasma concentrations of total and free progesterone, oestradiol-17 $\beta$ and LH in the cyclic ewe Theriogenology 28 417-426

SAS (1985) SAS User's Guide SAS Institute Cary, NC

Savio JD, Thatcher WW, Badinga L, de la Sota RL and Wolfenson D (1993) Regulation of dominant follicle turnover during the oestrous cycle in cows Joumal of Reproduction and Fertility 97 197-203

Schallenberger E, Schams D, Bullermann B and Walters DL (1984) Pulsatile secretion of gonadotrophins, ovarian steroids and ovarian oxytocin during prostaglandin-induced regression of the corpus luteum in the cow Journal of Reproduction and Fertility 71 493-501

Schillo KK, Alliston CW and Malven PV (1978) Plasma concentration of luteinizing hormone and prolactin in the ovariectomized ewe during induced hyperthermia Biology of Reproduction 19 306-313

Stott GH and Wiersma F (1976) Short term thermal relief for improved fertility in dairy cattle during hot weather International Journal of Biometeorology 20 344-349

Wise ME, Armstrong DV, Huber JT, Hunter R and Wiersma F (1988) Hormonal alterations in the lactating dairy cow in response to thermal stress journal of Dairy Science 71 2480-2485

Wolfenson D, Flamenbaum I and Berman A (1988) Hyperthermia and body energy store effects on estrous behavior, conception rate, and corpus luteum function in dairy cows Journal of Dairy Science 71 3497-3504

Wolfenson D, Thatcher WW, Badinga L, Savio JD, Philosof Y, Maman M, Meidan R and Berman A (1992) Alterations in follicular development and dominance during the estrous cycle in heat-stressed cows The 12th International Congress on Animal Reproduction, Vol. 4, 2117-2119, The Hague 